\title{
China's sustainable development and utilization of water resource conditions and protection
}

\author{
Rui Zhang, Wenjing Wei \\ Tianjin Bohai Vocational Technology College, \\ TianJin, China
}

\begin{abstract}
Analysis of the basic situation of water resources in china. The development and utilization of water resources and the protection countermeasures, in order to promote the sustainable development and utilization of water resources.
\end{abstract}

Keywords: sustainable development, water resources, Sustainable utilization

\section{CHINA'S WATER RESOURCES SITUATION}

\section{A. Water resources shortage}

Although our country has water 2.8 cubic meters, but the amount of freshwater resources per capita is only 2300 cubic meters, equivalent to the world average of $1 / 4$, was listed as one of 13 countries in the world the most depleted water. In 1998, China's per capita consumption of 2251 cubic meters, predicts that by 2030 China's population increased to 1600000000 , per capita water resources will be reduced to 1760 cubic meters. Experts predict that in 2010 China will enter a period of severe water shortage, water shortage in China in 2030 will reach 40000000000 to 50000000000 cubic meters. Water supply shortage, caused a great impact to the urban life and production. Part of the mountain, China's grasslands, coastal and island there are 60000000 people and 45000000 head of livestock drinking water very difficult. The annual agricultural output and industrial output due to lack of water caused heavy losses.

\section{B. China's water environment is getting worse, water resources utilization rate}

With the rapid development of the agricultural economy, population density increases, the phenomenon of waste water is very serious. At present, the effective utilization of agricultural irrigation water in China is only about $40 \%$, compared with the developed countries a lot worse, production unit of grain is two times more water irrigation methods developed country agriculture production in China still use the traditional flood irrigation, water is wasted greatly. China's million yuan output value of industrial water consumption is more than 100 cubic meters, is 10 times more than the developed countries, industrial water recycling rate was only thirty or forty per cent, the developed country is seventy or eighty per cent. In daily life, some people wash brush your teeth don't turn off the tap after using water, some not tightening the tap, and some people even open the tap "iced" fruit, or washing clothes. These "accidentally" behavior makes a lot of water passes.
The majority of urban tap water pipe network leakage phenomenon, causing water loss rate of $15 \%$ 20\%.

One of the important factors of water pollution is the leading cause of water shortage, water pollution in China is very serious. In recent years, the national annual emissions of nearly 600 tons of sewage, mostly untreated directly into the waters. Many of the original crystal clear lakes and rivers of water pollution and is not suitable for drinking. Due to the water resources immoderately claim, unreasonable development, cause soil erosion, shrinking lakes, rivers, water pollution, land desertification, ecological degradation, artificially aggravated the contradiction of water resources shortage.

\section{THE PRESENCE OF WATER RESOURCE PROBLEMS IN CHINA}

\section{A. The misunderstanding of the nature of water resources planning and management}

For a long time, the nature of the water resources problem a lot of people do not have a clear understanding, think water is "inexhaustible, inexhaustible", which resulted in a lot of areas, the Department did not plan or mismanagement, wanton built factories and expand the irrigation area, water resource abuse.

In China, the lack of unified planning and management of water resources. Water resources development, construction and management of different departments, resulting in the management work of the confusion. Although in recent years, water resources protection and monitoring project has some development, but not the irregularity, phenomena have occurred, or can not solve many problems to solve. Such as water trans basin pollution problem, occupies the floodplain blocking the river, river subarea management uncoordinated problem etc.

\section{B. Insufficient water supply capacity}

Since the founding of new China, China's water supply capacity from $103100000000 \mathrm{~m}$ in 19493 increase to $525000000000 \mathrm{~m}$ in 19933 about every 10 years to increase $100000000000 \mathrm{~m} \mathrm{3}$. But the ability of water supply growth can not meet the need of population growth and economic development demand for water, according to the present situation of annual water consumption statistics, in the middle of drought in China water shortage of about $35800000000 \mathrm{~m} \mathrm{3}$, the agricultural irrigation water shortage in $30000000000 \mathrm{~m} \mathrm{3}$, city (including industrial) water shortage $5800000000 \mathrm{~m} 3$. 


\section{Utilization rate is low, serious waste}

The phenomenon of wasting water in our country is very outstanding, agricultural water use accounts for about $70 \%$ of the total water use in the country, but the utilization coefficient of only $0.3 \sim 0.4$, unilateral aquatic food $0.85 \mathrm{~kg}$, while the developed countries of agricultural water use coefficient of $0.6 \sim 0.7$, unilateral aquatic food $125 \mathrm{~kg}$. China's industrial water recycling rate is only $30 \% \sim 40 \%$, and Japan and other developed countries, industrial water recycling rate from $70 \%$ to $80 \%$, the water consumption of the industrial products of China's high $1 \sim 10$ times than in developed countries. At present, China's urban living water per person per day is about $0.1 \mathrm{~m}$ about 3 , high also has reached $0.4 \mathrm{~m} 3$, the overall level is not high, but the waste of water is the universal existence phenomenon.

\section{Severe water pollution}

China is facing a serious problem of water pollution, the main pollution sources of industrial wastewater and urban sewage. At present, the total discharge of waste water each year in China, $300 \sim 40000000000 \mathrm{~m} \mathrm{3}$, of which more than $30 \%$ of industrial wastewater and $90 \%$ sewage without any treatment directly into rivers, causing $78 \%$ of urban river is not suitable for drinking water, $50 \%$ of urban groundwater pollution. China Lake hand because the area is deposition causes decreasing, nutrients and on the other hand, generally by the nitrogen and phosphorus pollution, eutrophication trend of further expansion.

\section{E. Groundwater overdraft}

Groundwater quality is good, pollution is relatively light, low treatment cost, is a good source of drinking water, groundwater exploitation has become the provisional measures temporary water supply shortages during the drought. But in some areas under the pressure of increasing demand for groundwater exploitation, has caused a series of problems, such as the formation of groundwater, land subsidence, seawater intrusion in coastal region. The continuous decline of the water table may cause the surface soil drying, the reduction of vegetation, soil erosion increased, resulting in a large area of desertification. The ecological environment transformation, further exacerbated the crisis of water resource.

\section{SUSTAINABLE DEVELOPMENT AND UTILIZATION OF WATER RESOURCES PROTECTION}

\section{A. The protection of water resources}

1) The meaning of water resources protection

The protection of water resources is a means to prevent inappropriate for water resources utilization caused by water pollution and destruction, the sum of the law, administration, economy, technology, education and other measures.

\section{2) The presence of water resources protection in China}

a) The development of environmental and resource economics, uncoordinated

The twenty-first Century is the century of sustainable development. Sustainable development not only for the development of contemporary people, but also to ensure the development of future generations, that is to say, the process of economic development must combine with the environment and resources protection of road. Over the years, our country exists generally short-term behavior in economic development, management, economic, light green, heavy development, light resources, heavy construction, light management. Based on the "prevention, combining prevention with control" policy implementation of poor, on economic construction, urban and rural construction and environmental construction must be "not synchronized planning, implementation and development" approach to cause our country taking the capitalist countries "pollution first, treatment after the development of the old road, always want the economy to more quickly. The faster the better, in fact, contrary to the laws of economic development.

b) Lack of water resources protection and monitoring of funds

In recent years, water resources protection and monitoring of funds investment is low, the water resources protection mechanism is not the main focus to management and supervision and monitoring business, at the same time, resulting in monitoring means lags behind the situation. The monitoring work of the current lack of automatic monitoring equipment, analytical instruments are relatively simple and old, lack of analytical instruments, do not suit with the monitoring task difficult, serious impact on a lot of essential for monitoring data.

c) Water resources protection policies and regulations system is not perfect

The lack of organic links between the various regulations of water resources management and water environment protection. The law environment, water conservancy of existing work on water resource protection provisions are not specific, is not clear, the lack of operability, did not fully reflect the strategic thought of coordinated development of environment and resources. The current environmental laws and regulations is only from the angle of environment management and protection of water resources, without taking into account from the perspective of water resources, water conservancy departments lack the protection of water resources unified regulations, work for arbitrarily large, no series of rules and regulations as the basis for the management and protection of water resources.

d) The lack of means of economic regulation of water resources protection

For a long time, due to the traditional theory, ideological constraints and the impact, in the use of resources is not really in accordance with economic laws, due to the pollution of water resources and the study on the value of loss is not enough, there is a loss of resources is not the 
issue of compensation. If the resource compensation economic mechanism is not established, will enable China's water pollution worsening trend is not effectively controlled. In addition, because there is no perfect economic mechanism of water resource protection, water resource protection and water quality monitoring funds has been to rely on state investment, but the national financial resources is limited, many funds difficult to implement, so that not only the protection of water resources and water quality monitoring existing difficult to do well, but also will affect the healthy development to the protection of water resources and water quality monitoring work.

3) Some countermeasures to solve the problem of water resources protection

a) Strengthen the construction of management system of water resources protection

Common problems of water resources protection in our country is a disordered state management. Should be an important measure to solve the problem of water resources protection in our country is to strengthen the unified management, make the management work, scientific, to national interests as the premise of the unified management of the track

b) Establish and perfect the system of policies and regulations for protection of water resources

Improve the legal system, and water is the basis and guarantee of water resources protection. Sum up the past, not only has promulgated the "environmental protection law", "water law", "water pollution prevention law", "water and soil conservation law", "river regulations" and "water permit system implementation measures" for the protection of water resources of the role, should also see a lot of water pollution and water environmental problems and legal system is not perfect, laws and policies are not perfect and the lax enforcement of the law of. Therefore, in addition to modify and improve the "water law", "river basin law" enacted, the law defines the water administrative departments in the water resources protection work in the position, responsibilities and rights, should also be formulated by the State Council promulgated the "protection of Water Resources Management Ordinance", to determine the total pollutant discharge control for river basin the core, local governments at all levels administrative heads of division of labor, river water resources protection mechanism to implement water resource protection mechanism of supervision. The department regulations to formulate methods for the administration of water resources protection river pollution supervision management, water quality at the prison meal management and water source protection.

c) The establishment of the market economic mechanism of water resources protection

Protection of water resources, water environment improvement, not only relates to the management system and policies and regulations, but also relates to how to adapt to the socialist market economy to gradually shake, the market economy mechanism lead to water resources protection work to problems. Water resource is the state- owned natural resources, water resources is the commodity for the users, should be paid for the use of. Therefore, in the concept to a big change, to change the existing under the planned economy, urban low-cost water, old system of the rural free water. Make use of the market mechanism to regulate the price of water and commercialization. The user should pay the water resource fee, including water supply investment cost, discharge of sewage treatment costs etc.. The price of water to classified management and computing, the user's use of water resources bear a reasonable economic responsibility. To use the incentive of water resources use economic leverage to save, play the greatest social and economic benefits.

d) Strengthen the protection of water resources capacity building

The increase of water resources protection investment, is to strengthen the protection of water resources ability construction, an important guarantee to enhance the comprehensive ability of water resources management. Therefore, governments at all levels should increase capital investment, strengthen the ability construction of water resources protection mechanism, to gradually improve the conventional water quality monitoring, to improve the mobility and rapid reaction capability of water environment monitoring system and automatic forecasting ability. The establishment of water quality information network common data exchange system and satellite communication based on the enhancement of the sudden water pollution accident warning, forecasting and prevention ability. The equipment used for the advanced equipments of aquatic organisms, trace elements and toxic and harmful substances testing, constantly improve the monitoring level and ability. Further do a good job in the management and technical personnel engaged in the work of water resources protection work of the job training, improve the overall quality of water resources protection team.

e) Strengthen the publicity and supervision

Water to homes and fields, in order to ensure that the water stability, good water quality, water resources utilization value into full play, must be deep lasting through newspapers, television, radio, magazines, manuals and other tools to carry out the propaganda and education of stereo type "saving people, improve the sense of responsibility and consciousness, rich water saving knowledge of people, so that every citizen aware that water is a precious resource, water is indispensable to life part, water reserves are limited, is a great contribution to the human race. Practice has proved that in developed countries, legal and administrative means, economic support and propaganda work, is considered one of the four elements for water resources management and protection work. Therefore, public opinion is an important part of water resources protection work well. Only to arouse the masses and the attention of the whole society, strengthen supervision, the people's Congress supervision of public opinion and supervision in all aspects, water resources can be protected. 


\section{B. Sustainable development and utilization of water resources}

Sustainable utilization of water resources is the management of water resources, people must take human utilization of water resources as a continuous process, is a whole; in the development and utilization of water resources in any period of this process must be in the water environmental capacity and water resources carrying capacity in the process of development and utilization of water resources capacity range and in the. The realization of economic benefits, environmental benefits and social benefits of unification and coordination, and realize the harmonious development of human society and nature.

\section{THE TOTAL NODE}

This paper analyzes the basic situation of water resources in china. Based on the analysis of existing water resources in our country, in order to make the water resources in China is sustainable development and use, and put forward a series of measures to protect water resources.

\section{REFERENCES}

[1] Liu Changming, Chen Zhikai. Analysis of the development trend of China water resources assessment and the supply and demand. China Water Conservancy and Hydropower Press, 2001, (3): 19 - 24

[2] Lina Gu. The comprehensive utilization of water resources planning and management of water conservancy and hydropower, 2005, (4): 68

[3] Yang Jian, Cui Chunlong, Zhao Min, Chen Qinghua. Land development and regulation, sustainable exploitation and utilization of water resources, 2002, (2): 10-13

[4] Chen Mingtao, Jie Cheng. Countermeasures of water resource assets management in China rural water and hydropower, 2006, (1): 52-53

[5] Jin Lin, Zhang can. Countermeasures for ecological economy, problems and protection of the water resources in China 1996 (1): 25-29 